\title{
Free Movement of Patients in Need for Cardiac Surgery
}

\author{
MIHAELA DACIANA NATEA ${ }^{1}$, OANA ELENA STOICA2*, FLORIN BUICU3 \\ 'University of Medicine, Pharmacy, Science and Technologies of Targu-Mures, Faculty of Sciences and Letters, History and \\ Political Sciences Department, 38 Gh. Marinescu Str., 540139, Targu-Mures, Romania \\ 2University of Medicine, Pharmacy, Science and Technologies of Targu-Mures, Faculty of Dental Medicine, 38 Gh. Marinescu Str., \\ 540139, Targu Mures, Romania \\ 3University of Medicine, Pharmacy, Science and Technologies of Targu-Mures, Faculty of Medicine, 38 Gh. Marinescu Str., 540139, \\ Targu Mures, Romania
}

\begin{abstract}
Free movement of patients is a core condition of the functioning of European free market rules in health's case. Nowadays, uniformizing practices and policies across Europe in patient's rights and access to medical care, based on EU norms, are important steps in generating a greater convergence and better opportunities for European citizens. In this context cross-border healthcare becomes a cornerstone in ensuring European citizens health especially if they cannot find suitable healthcare at home. In Romania more than 650 cases of E112/S2 forms are approved every year, on various diagnostic category. From all the cases, we followed in particular the ones regarding diseases and disorders of the circulatory system with a special emphasis on the septal defect cases approved for treatment abroad. From our findings, from all E112/S2forms approved cases most of them concern diseases and disorders of the circulatory system, and, from this, a significant part, are procedures correcting septal defects.
\end{abstract}

Keywords: corss-border healthcare, management, cardiac surgery, EU norms

The Treaty on the functioning of the European Union (TFEU) establishes in article 6 that protection and improvement of human health is under the competence of member states, except some common public health concerns[1]. This gives states the full authority to act in organizing the health system including the financing and insurance scheme for health service. But accessing health services fall under the provision of free movement of goods and services, meaning that patients should be able to move feely within the European Union(EU).

The foundation for cross-border healthcare is being laid by the EU Directive 2011/24/EU on the application of patients' rights in cross-border healthcare [2] which drafts the legal framework for receiving quality treatment in another EU country, with or without prior authorization and the reimbursement process. In an assessment report on the implementation of the Directive a conclusion was drown over the increase improvement of the legal framew ork across EU states in managing cross-border health care [3]. However, the Directive does not cover outof-pocket medical care, but sets up the bases for patients' mobility [4].

The European legal norms that lay the foundation for E112 form are: Regulation (EEC) No 1408/71 of the Council of 14 June 1971 on the application of social security schemes to employed persons and their families moving within the Community [5] and Regulation (EEC) No 574/ 72 of the Council fixing the procedure for implementing Regulation (EEC) No 1408/71 on the application of social security schemes to employed persons and their families moving within the Community [6].

According to the National House of Health Insurance (NHHI) there are two conditions in which the Form E112 is released. The first one is in case of transfer of the residence. In this case $E 112$ may be refused by the health insurance house onlyif it is established that the displacement of that person would be prejudicial to his / her state of health or medical treatment; The second on is for the condition of referral to medical treatment in casethe treatment in question is among the medical services provided in the basic services package that benefit the insured from the Romanian social health insurance system or this treatment cannot be given within the time period normally required for obtaining the treatment in question in Romania, taking into account the current health status of the patient and the probable evolution of the disease. [7]

The E112/S2 form allows access to planned medical treatment in other states, in the same conditions as for residents.

\section{Experimental part}

For the experimental part we used official statistics of the European Union regarding access to medical care in Europe andofficial data provided by the $\mathrm{NHHI}$ regarding total requests under E112 forms. NHHI also provided, at the request of the University of Medicine, Pharmacy, Sciences and Technology of Târgu Mure', extended data regarding E112/S2 approved requests for the last three years.

\section{Results and discussions}

The first aspect that must be taken into consideration is the reason for the need of cross-border health care.According to EUROSTAT there are reported unmet needs regarding medical care due to the cost, distance or waiting list as presented inEUROSTAT data which indicate a decrease both at European and national level with an average of 4\% in the EU 28 in 2016 and around 9\% in Romania [8] [11]. From the European countries,Estonia, Greece and Poland reported the highest percentage of unmet needs.Romania has a considerable decrease in the reported percentage of total unmet needs in medical but also dental care but is still high comparted to the European average. In the case of dental care this aspect could be linked to the considerable number of dental treatments done in the emergency service as shown in a study conducted over the cases presented in the Dental Office

\footnotetext{
* email: oanastoicaelena@gmail.com, Phone: 0747127603
} 
of Mures County Emergency Hospital in Targu-Mures during 2012-2017 [9]. In the case of medical care, the number can indicate also some type of treatments that cannot be provided in the country.

According to $\mathrm{NHHI}$ in 2017, $10.055 \mathrm{E}$ forms were received and analyzed. From that number only some received prior authorization [10].

In the case of E112/S2 form, from the data provided by $\mathrm{NHHI}$ some interesting facts emerged. In the timeframe from 2016-2017 an average of 650 cases were authorized. We structured the data on Major Diagnostic Category such as presented in Order 587/2013 in order to follow which are the most frequent request for treatmentabroad. As many are complex cases we selected one diagnostic category, the most urgent one, or the one for which the form was released, even if it implied a complex diagnostic. The data resulted are presented in Table 1 and Chart 1.
From the data presented, and comparing 2016 to 2017, we can conclude that the incidence of cases of the circulatory system that require treatment abroad is the highest, followed by diseases and disorders of the musculoskeletal system and connective tissue and diseases and disorders of the nervous system. Most cases involve surgical procedures, 551 cases in 2017, that cannot be done in Romania.

From the 264 cases concerning diseases and disorders of the circulatory system 98 have as main diagnostic or part of the diagnostic septal defect, and all of then required surgical procedures abroad. The age range is presented in the Table 2 which indicate that most of the cases are urgent ones, from newborns, in factmost of neonatal cases with E112/S2 approved treatment concern cases with sever diseases or disorders of the circulatory system, and include a form of septal defect.

\begin{tabular}{|c|c|c|c|}
\hline $\begin{array}{l}\text { Major } \\
\text { Diagnostic } \\
\text { Category }\end{array}$ & CMD & 2016 & 2017 \\
\hline CMD 01 & Diseases and disorders of the nervous system & 58 & 55 \\
\hline CMD 02 & Diseases and eye disorders & 20 & 26 \\
\hline CMD 03 & Diseases and disorders of the ear, nose, mouth and throat & 34 & 52 \\
\hline CMD 04 & Diseases and disorders of the respiratory system & 21 & 18 \\
\hline CMD 05 & Diseases and disorders of the circulatory system & 239 & 264 \\
\hline CMD 06 & Diseases and disorders of the digestive system & 31 & 35 \\
\hline CMD 07 & Diseases and disorders of the hepatobiliary system and of the pancreas & 22 & 9 \\
\hline CMD 08 & Diseases and disorders of the musculoskeletal system and connective tissue & 61 & 112 \\
\hline CMD 09 & Diseases and disorders of the skin, subcutaneous tissue and breast & 10 & 13 \\
\hline CMD 10 & Diseases and endocrine, nutritional and metabolic disorders & 0 & 4 \\
\hline CMD 11 & Diseases and disorders of the kidney and urinary tract & 20 & 16 \\
\hline CMD 12 & Diseases and disorders of the male reproductive system & 0 & 0 \\
\hline CMD 13 & Diseases and disorders of the female reproductive system & 4 & 5 \\
\hline CMD 14 & Pregnancy, birth & 10 & 9 \\
\hline CMD 15 & Newborns and other neonatals & 4 & 39 \\
\hline CMD 16 & $\begin{array}{l}\text { Diseases and disorders of blood and hematopoietic organs and immunological } \\
\text { disorders }\end{array}$ & 1 & 16 \\
\hline CMD 17 & Neoplastic disorders (hematological and solid neoplasms) & 26 & 27 \\
\hline CMD 18 & Infectious and parasitic diseases & 7 & 1 \\
\hline CMD 19 & Diseases and mental disorders & 0 & 2 \\
\hline CMD 20 & Alcohol / drug abuse and alcohol-induced organic mental disorders & 0 & 0 \\
\hline CMD 21 & Accidents, Poisoning and Toxic Effects of Medicines & 0 & 0 \\
\hline CMD 22 & burns & 18 & 2 \\
\hline CMD 23 & Factors that influence health and other contacts with health services & 1 & 3 \\
\hline
\end{tabular}

Table 1

Chart 1 -E112/S2 cases by Major Diagnostic Category

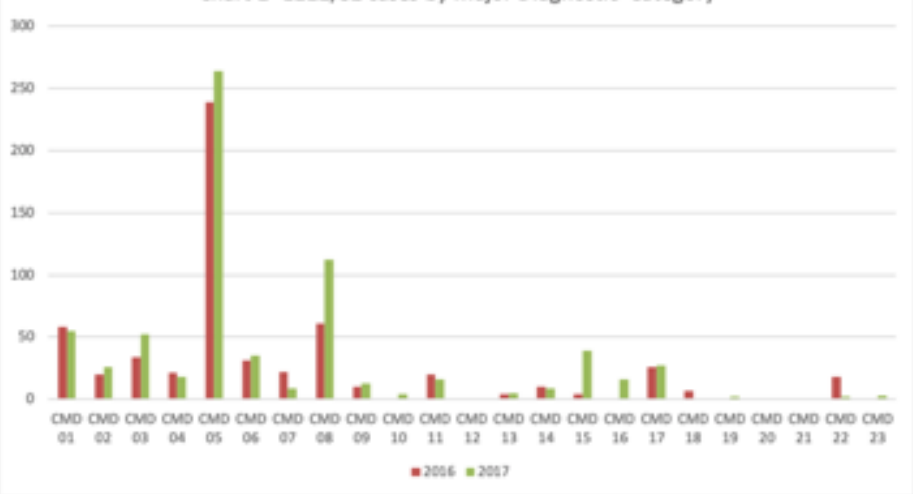

Chart 1
NUMBER OF SEPTAL DEFECT CASES BY YEAR OF BIRTH

\begin{tabular}{|c|c|c|}
\hline Nr. & Year of birth & No. of cases \\
\hline 1 & $1967-1990$ & 5 \\
\hline 2 & $1990-2000$ & 3 \\
\hline 3 & $2001-2010$ & 12 \\
\hline 4 & $2011-2015$ & 28 \\
\hline 5 & $2016-2017$ & 50 \\
\hline
\end{tabular}


The fact that so many cases are referred abroad for treatment indicate clearly a lack of national coverage for this type of diseases, due either to lack of infrastructure or medical professionals with competences in this field.

\section{Conclusions}

The need to medical healthcare abroad is obvious in the case of septal defect and the European systems offers a chance to life for the patients that can, in this manner, search for medical treatment abroad. The need to invest more in this area at national level is evident, and the investment shouldpursue better equipped hospitals and well-trained professionals. From a legislative viewpoint Romania implemented European laws, butsome problems were identified in the payment process, sometimes the state was unable to pay the bills for medical treatment in time.

\section{References}

1.*** Treaty on the functioning of the European Union, https://eurlex.europa.eu/legal-content/EN/TXT/PDF/?uri=CELEX:12012E/ TXT\&from $=E N$

2.*** EU Directive 2011/24/EU https://eur-lex.europa.eu/legal-content/ EN/TXT/PDF/?uri=CELEX:32011L0024\&from=EN .

3.*** Report from the Commission to the European Parliament and the Council on the operation of Directive 2011/24/EU on the application of patients' rights in cross border healthcare, 2018 p. 16, https://eurlex.europa.eu/resource.html?uri=cellar:bc5ac6d2-bd7c-11e8-99ee01aa75ed71a1.0019.02/DOC_1\&format=PDF .
4. MAINIL T, EIJ GELAAR E, KLIJS J, NAWIJ N J, PEETERSP, Research for TRAN Committee - Health tourism in the EU: a general investigation. European Parliament, Policy Department for Structural and Cohesion Policies, European Union, Brussels, 2017, p 56-57.

$5^{* * *}$ ( Regulation (EEC) No 1408/71 of the Council of 14 June 1971 on the application of social security schemes to employed persons and their families moving within the Community, https://eur-lex.europa.eu/ legal-content/EN/TXT/HTML/?uri=CELEX:31971R1408\&from =RO

6.*** Regulation (EEC) No 574/72 of the Council of 21 March 1972 fixing the procedure for implementing Regulation (EEC) No 1408/71 on the application of social security schemes to employed persons and their families moving within the Community, https:// publications.europa.eu/ro/publication-detail/-/publication/6530ce910e37-4a01-83db-854f6e5d994f/language-ro

7.*** National House of Health Insurance, E112 Form, http:// www.cnas.ro/casmb/post/type/national/precizari-privind-formularul-e112-1400156736.html

8.*** Eurostat Statistic Explained, Share of persons aged 16 and over reporting unmet needs for medical care examination or treatment, 2016,https://ec.europa.eu/eurostat/statistics-explained/index.php?title =File:Share_of_persons_aged_16_and_over_reporting_unmet_ needs_for_médical_care_examination_or_treatment,_2016.png

9. DORNER, K., MATHE KEREKE,S B, BORS, A, VARLAM, C.M., NIMIGEAN, V.R., SZEKEL, M., Patients Attendance for Emergency Dental Services in Mures County, Rev.Chim.(Bucharest),69, no.8, 2018, p.2115 10.*** NHHI, Annual activity report, 2017, http://www.cnas.ro/casmb/ media/pageFiles/CASMB_rap_activ_2017.pdf

11.***Special Eurobarometer 425 Patients' Rights in Cross-Border Healthcare,The European Union, Bruxelles, 2015, p.11; http:// ec.europa.eu/commfrontoffice/ publicopinion/archives/ ebs/ ebs_425_sum_en.pdf.

$\overline{\text { Manuscript received: } 19.11 .2019}$ 